\title{
Youths' Online Political Participation in Ethiopia; A Study of Students' Facebook Usage in Some Selected Public Universities
}

\author{
Ketemaw Muluye* \\ Department of Civic and Ethical Studies, University of Gondar \\ ${ }^{*}$ Corresponding author email: kmuluye@ yahoo.com \\ Received: 28 October 2018 / Revised: 03 December 2018 / Accepted: 21 January 2019 / Published: 02 February 2019
}

\begin{abstract}
This study was conducted to examine youths' online political participation in Ethiopia with a focus on students' Facebook usage in six randomly selected universities. The research specifically aimed to study the extent of participation, the main online political activities, and factors that determine such involvements. For this purpose, the research utilized a quantitative method with survey design. The sample size was 400 and the samples were selected by using the simple random method. Descriptive statistics were used for analysis. Accordingly, the research found limited youth's involvement in those activities that require more commitments and efforts while they found to be active in activities that require low efforts and commitments. Low political efficacy and fear of political measures were found to be the main factors that force youths to have limited involvement in activities that require more efforts and commitments.
\end{abstract}

Keywords: Ethiopian Students, Youth's Participation, Online Political Participation, Facebook usage, Social Media

\section{Introduction}

Political participation is the process of gathering and sharing of political information, interaction with politicians, participating in political campaign or taking part in voting exercise (Dalton, 2008). This definition is given with a focus on activities that are considered as political participations. Verba et al. cited in Dalton (2008) also characterized it as an activity that has the intent or effect of influencing government action - either directly by affecting the making or implementation of public policy or indirectly by influencing the selection of people who make those policies. Generally, by condensing all these definitions, we can define political participation as activities undertaken formally or informally, legally or illegally, individually or in-group with an intent and effect to influence decisions, actions and policies made by different government institutions. Based on their channel through which these political activities are conducted, political participation is divided in to two as offline and online (Ali \& Suhana, 2015). The offline political participations are the "traditional" political participations that are conducted through people intensive channels and mainstream media. Online political participations are political activities that are undertaken through the social media such as Facebook, Twitter, Blogs, Wikipedia and other internet services (Meesuwan et al., 2016). Researches conducted in different countries show that different political participations such as signing online petitions, electoral campaigns, seeking political information through online channels, articulating ones dissent and opinions and the like are being undertaken through the online channels (Abdu et'al.,2016; Ali \& Suhana, 2015; Li \& Marsh, 2008; Yang \& De Hart, 2016; Willnat, L. et'al, 2013). However, the socio-political setting at which these researches are conducted is different from Ethiopia and hence it is important to conduct a study that investigate the experience of Ethiopia.

Starting from recent time onwards, the Ethiopian youths are using the social media for undertaking political participation (Tesfaye, 2013). However, the situation of youths online political participation, particularly in relation to the main activities and extent of youth's involvement as well as factors that lower youth' political participation are not investigated. Previous studies are focusing on the potential of the media, the challenges 
and opportunities it brought as well as the benefits it gives. For example, the study conducted by Sleshie (2014) investigates the challenges and opportunities that Facebook brought to the Ethiopian population by using a quantitative research.

Tesfaye (2013) also studied the challenges and opportunities of Facebook in serving as channel of political communication in Ethiopia by using a qualitative method; and Ketemaw (2017) has studied the benefits, the challenges and weaknesses that political parties have acquired, faced and exhibited respectively when undertaking electoral campaigns through social media. Hence, the experiences of youth's online political participations are remained unexamined. As such, this paper intended to examine youth's political involvement in Ethiopia by focusing on university students. Accordingly, this research:

- Examined to what extent youths are undertaking political participation through Facebook;

- Identified the main online political participations undertaken by Facebook users; and

- Identified the major factors that force youths to be apathetic at online political activities.

\section{Research Method}

In this research, quantitative research method was employed. The data were collected through questionnaires from students of the six randomly selected universities of Ethiopia, in February 2018. The six universities were Jima University, Wollega University, Hawassa University, Wolyita Sodo University, Wachemo University and Debretabor University. These universities were selected randomly. The target population of this study was all BA degree students in the selected Universities during the $2010 \mathrm{EC}$ or 2017/18 GC academic year. The sample size was determined by using the simplified formula given by Yamane cited in Israel (1992, p. 4).

$$
\mathrm{n}=\frac{N}{1+N(e)^{2}}
$$

Where $\mathrm{N}$ is the total population, total number of students in the universities in this case, " $\mathrm{n}$ " is the sample size and "e" is the level of precision with an assumption of $95 \%$ confidence interval, 0.05 precision level and $0.05 \mathrm{P}$ value. Accordingly, the sample size was 400 from the 114,987 total populations. Once the sample size was determined, samples from each university were selected through stratified sampling method and to determine the sample size from each university, proportional allocation method was employed. Once the total sample size was determined in such a way, samples were selected from each department by using simple random sampling method. Finally, the data were analyzed through descriptive statistics. The research utilized frequencies and percentages to describe the findings.

\section{Result and Discussion}

\subsection{Demographic Characteristics of Respondents}

Demographically, the respondents have different social backgrounds. In terms of gender, males were the majority of respondents $(70 \%)$ while female cover $30 \%$ of the respondents. In terms of religion, the respondents were orthodox Christians (40.8), Muslims (33.2) Protestants (19.4\%) and others (6.5\%). As far as the ethnic background of the respondents is concerned, they were from different ethnic groups defined with eight codes. Generally, they were Amharas (11.8\%), Oromos (17.9\%), Haddiya (11.3\%), Tigre (2.5\%), Sidama (16.4\%), Wolayita (13.4\%), those who preferred to say Ethiopian (those who do not want to specify their ethnic background) (16.4\%) and others (10.3\%).

\subsection{Youth's Online Political Participation}

In this section, the research explored the major online political activities and the extent of youth's involvement in these activities. Regarding the data collection in this regard, first, list of common online political activities has been developed by reviewing different former researches conducted by different scholars and institutions. Then, respondents were asked if they participate in those political activities and to what extent they participate. The answers were leveled as "Yes Frequently", "Yes averagely", "Yes 
Ketemaw Muluye, Adv. J Social Sci.; Vol. 5 Issue 1, pp: 10-17, 2019

somehow" and "Not at all" and coded as 1, 2, 3 and 4 respectively. At the time of analysis, "yes frequently" and "yes, averagely" were merged and recorded as 1.

\subsubsection{Seeking Online Political Information}

The first online political activity is using the online media to have access for political information. Youths in different countries, as identified by the researchers such as Abdu et al. (2016), are using the online media particularly Facebook to update oneself about the ongoing political issues in one's own state. This research also founds that Ethiopian youths in the study area are showing a great interest and involvement in using Facebook as a main source of political information.

Table 1: Extent of Student's involvement in Seeking Online Political Information

\begin{tabular}{|c|c|c|}
\hline Do you use Facebook to have access of information on political issues? & Frequency & Percent \\
\hline Yes, Frequently & 277 & $69.3 \%$ \\
\hline Yes, Somehow & 123 & $30.8 \%$ \\
\hline Total & 400 & $100.0 \%$ \\
\hline
\end{tabular}

As it is presented in the above table (Table 1), the majority of the respondents $(69 \%)$ have stated that they frequently use Facebook to search political information and update themselves about the ongoing political issues in their country while $30.8 \%$ of the respondents are using it to some extent for this purpose. Though writers argued that a mere interest to have access for information should not be confused with political participation (Lamprianou, 2013), it is obvious that it gradually tends to create political assertiveness.

Particularly in countries where the mainstream media are under the control of the state, citizens prefer to use the social media as a preferable source of information (Ali \& Suhana, 2015). Ethiopia is one of such countries where there is strong control over the mainstream media and the media are serving as mouthpiece of the regime (Alemayehu, 2010). Privately owned media are target of frequent crackdowns by the government and people are devoid of alternative sources of information (Alemayehu, 2010; Teshome, 2009). Based on the survey that requests for a preferred source of political information, the majority replied that Facebook (41.3\%) and foreign-based mainstream media such as Voice of America (VOA hereafter), Ethiopian Satellite Television (ESAT hereafter), Oromia Media Network (OMN hereafter) and the like (41.3\%) are their preferences (See the table 2 below).

Table 2: Users' Preferred Source of Political Information in Ethiopia

\begin{tabular}{|c|c|c|}
\hline Which media you prefer to get information about politics? & Frequency & Percent \\
\hline Foreign based Media such as VOA, ESAT, OMN & 165 & $41.3 \%$ \\
\hline Government owned media such as EBC, OBN, AMA, SRTA & 63 & $15.8 \%$ \\
\hline Local based Private Media such as FBC, and ENN & 4 & $1.0 \%$ \\
\hline Facebook & 165 & $41.3 \%$ \\
\hline Local newspapers (both private and Government owned) & 3 & $0.8 \%$ \\
\hline 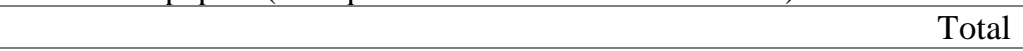 & 400 & $100.0 \%$ \\
\hline
\end{tabular}

This shows that how much the mainstream media in the state are lacking a trust on the side of the audiences while foreign-based mainstream media and Facebook are getting the attention of the people.

\subsubsection{Searching Likeminded Writers}

The other online political activity, which subtly related with access to information but sometimes which goes beyond a mere information seeking is searching writers of one's interest and those who undertakes political activism frequently. There are different Facebook pages and accounts with different issues such as religion, entertainment, job opportunity, politics and the like to discuss. Among the political issues again, there are different writers who post, analyze and update about various issues as per their interest and goal. This research found that the majority of users (54\%) are frequently searching likeminded writers while some $(12 \%)$ are searching likeminded writers to some extent. According to the use and gratification theory, users 
Youths' Online Political Participation in Ethiopia; A Study of Students' Facebook Usage in Some Selected Public Universities

are active who chose the medium and the content based on their own interest (Rienhard \& Dervin, 2009). That means, despite there are many writers with different political objectives and interests, it is not the media and its contents that direct them as proposed by technological determinism theory.

\subsubsection{Information Distribution}

The third online political activity conducted on Facebook is sharing the political ideas of others either through copy-paste or by direct clicking on the "share" button. It is an involvement for information dissemination like pamphlet distribution of the offline channels. In this case, youths are not involved in providing their political opinion, analysis or commentary rather their focus is on the disseminations of political ideas and opinions forwarded by others. This information dissemination is essential to update one's friend or follower about different political ideas and occurrences. Sharing the political ideas and opinions of others, which is posted via other's Facebook account/page, is identified to be at the lowest of online political participation since the commitment and effort of engagements are relatively low. Of course, it requires better political assertiveness as compared to reading political information alone on Facebook.

Regarding to what extent youths in the selected universities are involved in sharing the political idea and information, the majority of the respondents have replied that they frequently undertaken this activity. The survey found that $65 \%$ of the respondents replied that they frequently disseminate through a share button while $15 \%$ replied that they undertake it o some extent. However, the critical issue in this regard is the presentation and dissemination of propagandas and fake news, which leads to instability and even affects the reliability of the online media. In this regard, Ketemaw (2017) has found that the behavior of the online society particularly, the dissemination of fake or uncertain information as one of the challenges to use social media for electoral campaigns in Ethiopia. Hence, it is very important for the online society to ensure the trustworthiness of the information before sharing.

Nevertheless, the question is how many of the social media users are doing this task. According to my survey, majority of the respondents do not pay a due attention to ensure whether the information they have accessed is genuine and its source is trustworthy.

Table 3: Percentage of Users who tried to ensure trustworthiness of information on Facebook

\begin{tabular}{|c|c|c|}
\hline Do you ensure trustworthiness of information? & Frequency & Percent \\
\hline Yes & 137 & $34.5 \%$ \\
\hline No & 260 & $65.5 \%$ \\
\hline Total & 400 & $100.0 \%$ \\
\hline
\end{tabular}

As it is viewed from table 3 , from the total surveyed populations, only $34.5 \%$ reply that they try to ensure the trust-worthiness of information posted on Facebook (See Table 3). That means the vast majority are found to share without ensuring the trustworthiness of the information they receive. Given that the medium is conducive for everyone to post and disseminate what he/ she wishes, it is very important to pay attention to its trustworthiness while using social media as a source of information and channel of dissemination.

\subsubsection{Posting Political Analysis, Dissents, and Information}

The other political activity conducted through Facebook is being a producer. In this activity, Facebook users write and post about what is going on in their localities. By using the media, they provide a political analysis over various political issues. In addition, they post, the day-to-day feelings and opinions related to politics and share it to their followers. It is believed that the social media, mainly Facebook is becoming one of the essential channels to express political dissents and alternative political views, particularly in countries where the mainstream media are not free to accommodate such views (Gong, 2011). Ethiopia is one of such countries where the alternative channels of political communication are less accommodative to diversified views (EIU, 2017). Based on the survey, Facebook is leveled as a preferred media outlet to 
Ketemaw Muluye, Adv. J Social Sci.; Vol. 5 Issue 1, pp: 10-17, 2019

post and share one's own political feelings, dissents and analysis as compared to the other channels of communication in Ethiopia (See Table 4).

Table 4: Users' preference of media to express political dissents and opinions

\begin{tabular}{|l|c|c|}
\hline $\begin{array}{l}\text { Which media is preferable to convey ones dissent on and opinion about } \\
\text { the political issues of the country? }\end{array}$ & Frequency & Percent \\
\hline Foreign based Media such as VOA, ESAT, OMN.. & 27 & $6.8 \%$ \\
\hline People Intensive Channels & 43 & $10.8 \%$ \\
\hline Facebook & 305 & $76.3 \%$ \\
\hline Government owned media such as EBC, OBN, AMA, SRTA... & 12 & $3.0 \%$ \\
\hline Local based Private Media such as FBC, ENN... & 13 & $3.3 \%$ \\
\hline
\end{tabular}

Despite the research found that Facebook is the relatively preferred media to express dissents and opinions, the majority of respondent $(46 \%)$ reply that they do not post their own political commentaries. The majority of the respondents (46\%) replied that they are not posting political opinions and analysis through Facebook followed by those who frequently do it $(35 \%)$ and those who update their status with political analysis and opinions to some extent (19\%).

\subsubsection{Mobilization and Campaign Activities}

These online political involvements call for action to be conducted on the ground. Youths use the social media to organize and call for demonstrations, protests, strikes, boycotts, road blockings and the like for different political objectives. The utilization of social media for mobilization and campaign activities are identified as unconventional political participation (Lamprianou, 2013; Munroe, 2010). Regarding the Ethiopian experience, this survey conducted on students of the selected universities found that a very limited number of respondents reply that they frequently $(19 \%)$ and somehow $(17 \%)$ involved in such activities while the majority $(64 \%)$ replied that they do not involve in mobilization and campaign activities due to different reasons. This shows that the largest section of the online media users among Ethiopian students is not using for such mobilization activities. The result is presented in the following table 5.

Table 5: Involvement in Mobilization and Campaign Activities

\begin{tabular}{|c|c|c|}
\hline Do you undertake online mobilizations and campaigns for a political cause? & Frequency & Percent \\
\hline Yes, Frequently & 79 & $19.8 \%$ \\
\hline Yes, Somehow & 67 & $16.8 \%$ \\
\hline Not at all & 254 & $63.5 \%$ \\
\hline Total & 400 & $100.0 \%$ \\
\hline
\end{tabular}

\subsubsection{Political Discussion and Debates through Comments}

In this case, you are not generating ideas of discussion or debate rather you get involved to react on the ideas and opinions, which came in to the floor by someone else. The reactions may by either by supporting or opposing the political ideas and opinions raised by others. The surveys revealed that majority of the respondents (52\%) are not involved in these activities.

\subsubsection{Signing Online Petitions}

Signing petitions has long been one of the more popular political activities, leading the field for participatory acts outside voting, and with other social benefits such as civic mindedness (Willnat et 'al., 2013). Although there are start-up costs in getting to know the platform for people who initiate petitions, organizers can find supporters more easily, rather than having to canvass them door-to-door or approach people in the street. For those wishing to sign petitions, the search costs are far lower: they may sign a petition instantly on receipt of an email or post on asocial networking site. Furthermore, every petition signer is now potentially a petition organizer given the ease with which petitions can be disseminated to one's contacts 
via social media. With these reduced transactional costs and the ease of coordination, online petitions are becoming one important aspect of political activities (Hale et 'al., 2014).

In Ethiopia, there were various online petitions created for different purpose by different individuals and institutions. There was an online petition created by Diaspora against the election of Tewodros Adhanom for WHO and its antithetical petition in support of him for the position. There was a petition by Oromo Diasporas against Professor Lapiso G. Delebo, and a petition by Amhran activists against the forceful eviction and murdering of Amhara in different parts of the country to mention few. However, the involvement of Ethiopian youths in such activities is found to be limited. The survey shows that, the vast majority of respondents $(76 \%)$ have never signed an online petition that was organized and disseminated through Facebook. The research found that only 7\% are actively involved in such activities while the remaining $18 \%$ are involved to some extent. It is the one of the list performed online political activity as revealed from the samples in the selected universities.

\subsubsection{Joining Online Fund-Raising Campaigns for Political Parties}

This online political activity is basically intended to collect money for political parties. In many states, the fund raising is conducted through the use of different online applications. However, online systems through which one can donate money to a political party are not yet started in Ethiopia. Hence, what the online society can do in this regard is conducting an online mobilization through the dissemination of fundraising campaigns to undertake an offline action. However, almost all of the respondents $(99 \%)$ have replied that they have never been involved in such activities on Facebook. Though this might be due to different reasons one may thought that it is because of the parties may not initiate such campaigns or the users may not have access to the parties' page. Moreover, the youths may not have an interest in a party politics or due to other factors that we will see.

\subsection{Why Youths are Apathetic in the 'Main' Online Political Activities?}

As illustrated so far, the political involvement of youths in activities that require more effort and commitment is found to be minimal as it is compared to activities such as information seeking and searching likeminded writers. The question is why youth's participation is found to be limited in these activities. By taking the variables from Liberal and Participatory theories of democracy, this research examined the main factors that force the youths to have limited online political involvement in activities that require more efforts and commitments.

Table 6: Factors that lower Youths Online Political Participation

\begin{tabular}{|l|l|l|l|l|}
\hline Why you do not have active participation on online political & \multicolumn{4}{|c|}{ Responses } \\
\cline { 2 - 5 } \\
activities? & Frequency & Percentage (\%) \\
\cline { 2 - 5 } & Yes & No & Yes & No \\
\hline Because I don't have interest to take part in politics & 79 & 321 & $19.8 \%$ & $80.2 \%$ \\
\hline Because I don't have knowledge about politics & 47 & 353 & $11.8 \%$ & $88.2 \%$ \\
\hline Because I don't get information on political events & 35 & 365 & $8.8 \%$ & $91.2 \%$ \\
\hline Because I fear political measures & 243 & 157 & $60.8 \%$ & $39.2 \%$ \\
\hline I feel that my involvement has not value & 250 & 150 & $62.5 \%$ & $37.5 \%$ \\
\hline Because I don't have interest to take part in politics & 79 & 321 & $19.8 \%$ & $80.2 \%$ \\
\hline
\end{tabular}

As it is shown in table 6 , the fear of political measures and low political efficacy were found to be that main factors that forced youths' to be apathetic at online political activities. This finding is in contradiction to liberal theory of democracy. The liberal theory claims that "citizens of contemporary societies are marked by low interest in and poor knowledge and information about politics; therefore, their willingness to 
Ketemaw Muluye, Adv.J Social Sci.; Vol. 5 Issue 1, pp: 10-17, 2019

participate in politics would also be rather low (Bengü Hosch-Dayican, 2010, p.32). However, this research found that lack of interest (19.8\%), lack of knowledge (11.8\%) and lack of information (8.8\%) as having a lower degree of influence in making youths to be apathetic at online political activities. Instead, the research found that youth's are tend to be apathetic not because they lack the interest or information or knowledge, rather because of the fear of political measures $(60.8 \%)$ and low political efficacy $(62.5 \%)$. This is supported by the participatory theory of democracy which claims as "citizens are not apathetic because they are not interested in politics, rather they are simply not able to control the outcomes through the available channels, and therefore remain passive (Bengü Hosch-Dayican, 2010, p.38). Tronvoll (2001) also shows how the fear of political measure curtails Ethiopian citizens from undertaking effective political involvement. In terms of the online media, the arrest and the detention taken against the Zone 9 bloggers has left a bad image on online political activism though they are released as free after almost a two years detention (Freedom House, 2015). Generally, though the lack of political interest, knowledge and information in politics are claimed to be factors that lower youth's interest to take part in politics, this research found that youths in Ethiopia are preferred to be apathetic in online political activities because of low political efficacy and fear of political measures such as arrest, los of job and killings.

\section{Conclusion}

Based on the data presented and analyzed so far, the following conclusions are drawn pursuant to the specific objective. Regarding the extent of using social media for undertaking active political participation, the majority of the respondents were found to be participant in those activities that are placed at the lower level in the degree of political activism. The youths were found to be active in searching for political information, recruiting and searching Facebook pages as well as sharing the political opinions of others through share button or direct copy-paste. On the other hand, the involvement of youths in political discussions through chats and comments; in producing and posting one's political analysis, information and opinions; online campaigns and mobilizations; in fund raising campaigns for political parties and in signing online petitions were found to be below average. These shows that, youths are not that much involved in online political activities that required relatively high level of commitments and efforts. Moreover, it shows that such activities are conducted by relatively few social media users while others are simply readers and to some extent distributors. The research found that the involvement of youth's in such activities is relatively low because of the fear of political measures for being involved and because of the believe that their participation has not value in influencing decision-making process of the regime.

\section{Acknowledgment}

This research was sponsored by Wachemo University and the Author duly acknowledged that.

\section{Conflict of Interest}

The Author has no any conflict of interest

\section{How to Cite this Article:}

Muluye, K. (2019). Youths' Online Political Participation in Ethiopia; A Study of Students' Facebook Usage in Some Selected Public Universities. Advanced Journal of Social Science, 5(1), 10-17. Doi: 10.21467/ajss.5.1.10-17

\section{References}

Abdu, D. et'al. (2016). New perspectives to political participation among youth: The impact of Facebook usage. The European proceedings of Social and Behavioral sciences, 128-134.

Alemayehu G.M. (2010). Cartoon Democracy: Ethiopia's 2010 Election. International Journal of Ethiopian Studies, 5, (2), 27-51. Tsehai Publishers.

Ali,S. \& Suhana, S. (2015). Online political participation: A study of youth usage of new media. Mediterranean Journal of Social Sciences, 6 (4). MCSER Publishing. Rome, Italy.

Arriola, R. (2007). The Ethiopian voter: An assessment of economic and ethnic influences with Survey data. International Journal of Ethiopian Studies, 3 (1), 73-79. 
Youths' Online Political Participation in Ethiopia; A Study of Students' Facebook. Usage in Some Selected Public Universities

Bengü Hosch-Dayican. (2010). Political Involvement and Democracy: How Benign is the Future of Post-Industrial Politics. PhD Thesis, University of Twente, The Netherlands.

Freedom House. (2015). Ethiopia: Country report on the net/2015.

Dalton, R. J. (2008). Citizenship norms and the expansion of political participation. Political Studies, 56(1), 76-98.

Gong, R. (2011). Internet politics and state media control: Candidate weblogs in Malaysia. Sociological Perspectives, 54 (3), 307-328. SAGE publications.

Israel, D. Glenn. (1992). Determining sample size. University of Florida. PEOD.

Ketemaw M. (2017). The status of political parties in using social media for electoral campaigns in the 2015 general election of Ethiopia. African Journal of Political Science and International Relations, 11(10), 284-300.

Lamprianou, L. (2013). Political participation research: A critical assessment. In Demetrio (ed.) "Democracy in Transition". Springer-Verlag.

Li, Y. and Marsh, D. (2008). New forms of political participation: searching for expert citizens and everyday makers. British Journal of Political Science, 38 (2), 247-272. Cambridge University Press.

Meesuwan, S. 2016. The effect of Internet use on political participation: Could the Internet increase political participation in Thailand? International Journal of Asia Pacific Studies 12 (2): 57-82

Rienhard, C. \& Dervin, B. (2009). Media uses and gratifications. In Eadie, W (Ed.). 21st Century Communication: A Handbook (pp. 1-25).

Sileshie S. (2014). Challenges and opportunities of Facebook as media platform in Ethiopia. Journal of Media and Communication studies, 6(7), 99-110.

Tesfaye A. (2013). Social media as an alternative political forum in Ethiopia: The case of Facebook. MA Thesis. Addis Ababa University.

Teshome, W. (2009). Media and multi-party elections in Africa: the case of Ethiopia. International Journal of Human Sciences, 6(1), 94-122.

Willnat, L. et‘al (2013). Online Media and Political Participation: The Case of Malaysia. Mass Communication and Society 16, 557-58. Rutledge publication.

Yang and De Hart (2016). Social media use and online political participation among college students during the US election 2012. Social media+ Society, $1-18$.

Publish your research article in AIJR journals-

$\checkmark$ Online Submission and Tracking

$\checkmark$ Peer-Reviewed

$\checkmark$ Rapid decision

$\checkmark \quad$ Immediate Publication after acceptance

$\checkmark$ Articles freely available online

$\checkmark \quad$ Retain full copyright of your article.

Submit your article at journals.aijr.in
Publish your books with AIJR publisher-

$\checkmark \quad$ Publish with ISBN and DOI.

$\checkmark$ Publish Thesis/Dissertation as Monograph.

$\checkmark$ Publish Book Monograph.

$\checkmark \quad$ Publish Edited Volume/ Book.

$\checkmark$ Publish Conference Proceedings

$\checkmark$ Retain full copyright of your books.

Submit your manuscript at books.aijr.org 